\title{
Analyzing the Use of Mobile Phone Technology in Access and Utilization of Library Resources in Mount Kenya University, Kisii Campus
}

\author{
Benard Omallah George ${ }^{1, *}$, Jane Maina ${ }^{2}$, Lucas Wamalwa Wanangeye ${ }^{1}$ \\ ${ }^{1}$ Mount Kenya University, Kisii Campus, Kenya \\ ${ }^{2}$ Faculty of information Science and Technology, Kisii University, Kenya
}

Copyright $\bigcirc 2016$ by authors, all rights reserved. Authors agree that this article remains permanently open access under the terms of the Creative Commons Attribution License 4.0 International License

\begin{abstract}
Tremendous advancements attained in the last one decade in computer and mobile phone technologies have completely changed patrons' information seeking behavior and left librarians and information professionals rethinking about ways of re-engineering library resources to foster their utility. Libraries and information centres have invested heavily on holding library resources and services from different disciplines in a frantic move to address users' needs but limited readership is still recorded. In this paper, the researcher delved into analyzing the use of mobile phone technology in access and utilization of library resources and services as a way of re-engineering library holdings to promote their (library resources and services) consumption. The targeted population was Mount Kenya University Kisii campus library users. A cross sectional survey research design aimed at identifying library users' perception on the use of mobile phone technology was used. Stratified sampling was used to identify the students-respondents and purposive sampling used to select the library staff. While questionnaires were placed to collect the data from students, library staff respondents were interviewed. The study sample comprised four hundred (445) library users and staff out of a population of three thousand five hundred and twenty eight (1467). Once the data collection is complete, quantitative data was analyzed using descriptive statistics such as mean, distributions in percentages and frequency counts. Qualitative data was recorded from field data, transcribed and reported in themes and sub themes. The study showed among other findings, that there are increased retrieval and use of library resources and services through the use mobile phone technology in Mount Kenya University Kisii Campus.
\end{abstract}

Keywords Mobile Phone Technology, Access, Utilization, Library Resources, Patrons, Re-engineering

\section{Introduction}

Exponential growth in adoption and use of both computer and mobile phone technologies have immensely changed information seeking characteristics of all library user resulting librarians and other information professionals going back to drawing board to establish new mechanisms to provides library resources. Simmonds \& Andaleeb, (2001) concurs that with emphasis being placed on electronic resources, and users being more interested in access rather than actual ownership, libraries are facing greater competition from many sources like bookstores and information from publishers and vendors who try to provide some of the same services that libraries provide. Rieger \& Gay, (1997) adds that teaching and learning cannot be adequately replicated using advanced multimedia technologies, the computer's prowess and mobile phone capabilities at information organizing and retrieval can be taken to class to support access and utilization of library resources. According to data collected by the International Telecommunications Union, between 2002 and 2008 (the latest date for which the ITU has data), mobile cellular subscriptions in Africa have skyrocketed, greatly outpacing the slight increase in Internet subscriptions, while fixed telephone lines and fixed broadband subscriptions have remained nearly flat(Maranto, Phang, \& Hartman, 2010) Widespread mobile phone ownership among this social group means there is an opportunity to provide them with pertinent information that could help them grow academically and support government policy formulation and implementation (Wyche, Densmore, \& Geyer, 2015).

The typical American teenager is sending and receiving a greater number of texts now than it was in 2009(Lenhart, 2009). In 2004, a survey showed that $45 \%$ of teenagers had a cell phone and the use has climbed steadily among teens to $63 \%$ in 2006 and $71 \%$ in 2008(Lenhart, 2012). The steady increase in use of mobile phone in social arena has also impacted significantly in the access and utilization of library resources and services where patrons are currently interacting with library staff, library catalogues and other 
customized library services through mobile phones.

The developing countries of Sub-Saharan Africa have lagged far behind the developed nations, East Asia, and even the Middle East and Latin America in their access to information, and especially to and communication technologies (ICT) and digital information (Maranto et al., 2010). They add that until recently, access to ICT in developing countries has focused on computers and Internet access hence, the vast growth in mobile telephones as a form of ICT in Africa provides a new model of information access, one that surmounts many of the traditional barriers to information and may enable Sub-Saharan African development.

Mobile (cell) phone communication has been suggested as a method to improve (Lester et al., 2010) access and utilization of library services in Kenya since there remarkable trend in adoption and use of mobile phone throughout Kenya. According to research commissioned by Communication Authority of Kenya, although Kenya's population is currently enjoying the $4 \mathrm{G}$ mobile signals, recent research found out that more than 2.5 million Kenyans have no access to voice services and $55 \%$ of the country's land mass is yet to covered by $2 \mathrm{G}$ mobile signals. Nevertheless, the government is going to spend $1.5 \mathrm{~B}$ in the year 2016 in connecting parts of the country starved of mobile and broadband access (Standard, 2016). These are elementary milestone attempts done by the government to invest in strong mobile phone infrastructure to promote and engender information access and utilization in Kenya.

Libraries and information centres have also invested heavily in developing mobile phone access enabling infrastructure in their attempt to meet user needs. Mount Kenya University (MKU) has created a strong library management system that offers ample platform to library users to interact with library services. MKU E-repository affords to users access to books, journal, conference papers, projects, research papers, thesis and dissertations, university publications and virtue varsity modules. MKU Online Public Access Catalogue (OPAC) offers an account to all patrons where they can customize, confirm books borrowed and renew borrowed resources without physically going to library premises. Multi-media (e-learning section) of MKU library hold kindle (e-book readers) which are available to library users on demand. Kindle are used within library premises to access and utilize e-resources. Therefore, with this investment to promote remote access to library resources in MKU libraries, the research sought to address the following questions; (i) how are library services accessed and utilized in Mount Kenya University library services? (ii) How can mobile phone technology be used in access and utilization of library resources? (iii) What challenges are encountered in using mobile phone technologies in access and utilization of library resources? (iv)What solution can resolve challenges of using mobile phone technologies in access and utilization of library resources?

\section{Literature Review}

Mobile phone technological advancement, political goodwill, information proliferation and developed information communication technology have all transformed the provision of library services in Kenya. Mobile data technologies are wireless technologies which are built in mobile devices and provide information interchange between mobile devices and other devices or networks and can improve library service delivery as they are not limited by place and time (Onyango, Ongus, Awuor \& Nyamboga, 2014). Many libraries could improve access to library resources by providing guidance to the content of e-resource packages, by including the word "book" in links from the homepage to the pages that provide e-books, by providing a one-step limit to library resources in the catalog, by explaining which types of resources are available through search structures outside the catalog, and by featuring e-books in library publicity and instruction (Dinkelman \& Stacy-Bates, 2007). Pomerantz \& Marchionini (2007) argues that a library is more than a pile of books and creates value to information resources by organizing them and making them available. With technological advancement, a lot of considerations have to be brought on board when attempting to create library databases.

The library of the future has been described as "a portal through which students and faculty will access the vast amount of information resources in the world and less a place where information is kept" as focus shifts from ownership of information to access to and management of information (MacWhinnie, 2003). Libraries are redesigning their services and space to accommodate the changing needs and the demands for technology. Mac Whinnie adds that students can use computer workstations (multi-media library section) to access the Online public Access Catalogues (OPACs), search the Internet and electronic databases, and use productivity software to prepare assignments with print resources, technical help, and professional research assistance readily available from library staff. The increasing prevalence of handheld mobile computing devices such as PDAs and web-enabled cell phones warrants investigation as to its impact on libraries and the services they provide (Cummings, Merrill, \& Borrelli, 2010)

Lippincott, (2010) states that mobile devices include laptops, netbooks, notebook computers, cell phones, audio players such as MP3 players, cameras, and other items. This study will focus on smartphones (and assumes the inclusion of the iPod Touch, which has the features of a smartphone minus traditional telephone capabilities) and e-book readers such as kindles. Attempts to demonstrate that cell phones may in future provide solutions to libraries problems of connectivity to patrons especially in the remote areas of the Southern African Development Community member states is evident in the recent developments in mobile technology (Mutula, 2002). A part from fast internet connectivity afforded by smartphone to their users, they are portable and have relatively large screens that provide friendlier interface 
for users to access and utilize information without straining the eyes (Gitau, Marsden, \& Donner, 2010). Since Kenya has experienced exponential interest and use of the 4G network for mobile phone (Ishii, 2004), Varshney \& Jain, (2001) found out that with this feature, users will have access to different services, increased coverage, the convenience of a single device, one bill with reduced total access cost, and more reliable wireless access even with the failure or loss of one or more networks. With friendly user-interface, use $4 \mathrm{G}$ networks, sophisticated hardware and software all integrated with library management systems, library services can be accessed and utilized quickly and easily.

Zhang et al., (2010) asserted that there is tension between the interest in potentially power-hungry smartphone application features and the requirement for low power consumption necessary for long battery lifespans. Intermec (2010) also observed that the quality of some phone is too low to last a year, 'Many of these same phones will be replaced within a year because they are not durable enough to work reliably in new enterprise work environments'. (Ahmed, Raza, \& Sadik, 2014) added that Smartphones are overwhelmingly considered as one of the most viral technological advancements in handheld and mobile computing but usability is still a challenge especially among elderly people. Despite Mobile devices becoming increasingly integrated into various aspects of our daily lives including teaching and learning platforms, their screen size and resolution restrict mobile phones in displaying information content, (Ali, Alrasheedi, Ouda, \& Capretz, 2014). As such, Ali et al. adds that mobile applications used for educational purposes have a complex user interface (UI) with many hidden options, designing and developing attractive user-friendly mobile applications is a way to be explored.

Although the challenges trying to impede the use of mobile phone technology in access and utilization are immense, attempts are done to subvert the prevailing conditions. Viet-Linh (2013) showed a big gap between the potential demand and the current diffusion of smartphone for elderly and proposed that phone programming must have elderly people in mind. Ahmed, Raza \& Sadik (2014) addressed the question of user friendliness where they discovered that sleek and neat design is one of the necessary factors for influencing user adoption. Ali et al., (2014) adds that in the educational sector, mobile phones are being used as the platform for teaching and learning and smartphones are being integrated within existing education systems to support real-time communication and deliver learning materials. This is possible when mobile technology is born with the user in mind.

Mobile phone capabilities and use overrides the challenges presented by the same. Therefore, the use of devices in access and utilization of library services is the way to go. It will address programmes diversity and spaces issues in the provision of the said services.

\section{Research Methodology}

In this study the researchers employed a cross sectional survey research design whereby the perceptions and responses as held by the respondents were studied. A cross sectional research design is a present oriented methodology used to investigate populations by selecting samples to analyze and discover occurrences at a particular point in time (Onyango, Ongus, Awuor, \& Nyamboga, 2014).

The study was conducted among selected Mount Kenya University campuses and the study population consisted of 1467 library users and staff. Mount Kenya University (MKU) campuses that were purposively selected for this study were Thika main, Nairobi, Nakuru, Eldoret, Kitale and Kakamega. The respondents comprised of university librarian, campus librarians from selected campuses, system librarian and students.

According to Yamane (1967), the formula to calculate sample sizes when the population under study is less than ten thousand is simplified as below:

$$
n=\frac{N}{1+N e^{2}}
$$

Where; $\mathrm{n}=$ sample size

$\mathrm{N}=$ the population size, and

$\mathrm{e}=$ level of Co-efficient precision. A $95 \%$ confidence level and,

From the above formula, the sample size for the study was derived as follows:

$$
\mathrm{n}=\frac{1467}{1+1467(0.5)^{2}}=398.91 \approx 400.0
$$

The study used a $95 \%$ confidence level, this meant that if the same population was sampled on numerous occasions and interval estimates are made on each occasion, the resulting intervals would result to the true population parameter in approximately $95 \%$ of the cases sampled and $\mathrm{P}$ $=0.5$ which means that the probability of the difference having happened by chance is 0.5 in 1 .

Both purposeful and stratified sampling techniques were used in this study. Purposive sampling technique was used to select University and Campus Librarians. The technique was adopted because university and campus librarians in-charge of libraries and its one individual per campus. Similarly, the same technique was employed when selecting systems librarians from each campus. Stratified sampling was employed in selecting a sample from the students' body. This technique was used because students will be grouped based on their year of study; their (students) population is not homogenous. Each year of study will constitute a stratum.

In this study, both questionnaires and interviews were used to collect data. Interview is a well-established method of data collection used to measure opinions and attitudes of respondents on a particular problem under investigation (Khan, 2008). This method was used to collect information from library staff members. University librarian and campus librarians being the individuals' in-charge of library 
resources, they provided user statistics based on technology under investigation and permission to interview system librarians. System librarians provided information on usage of mobile phone to access library services. Similarly, questionnaires were administered to the students in the six campuses in order to obtain their attitude, opinion, comment and viewpoint about use of mobile phone technology in access and utilization of library services.

Content validity of the research instruments was done to ensure that the instrument gathered the information the study purports to collect (Onyango et al., 2014), which is achieved by expert judgement (Gay, 2005). Therefore, the validity of research instruments relied on the expert advice of Dr. Jane Maina (Supervisor) of the Faculty of Information Science and Technology - Kisii University. The questionnaire was also piloted in Mount Kenya University-Kisii Campus, one of Mount Kenya university campus which is not one of the selected campuses for this study to test reliability.

Data analysis on collected field data was done according to the research objectives. The data collected was cleaned, edited, and coded before they are entered into the statistical software for analysis. Statistical Package for Social Sciences (SPSS) and Excel was used for analyzing the collected data. SPSS was preferred because of its ability to model latent variables under both normal and non-normal conditions (Odongo, 20011). Excel was also used to generate and manipulate graphs and charts.

\section{Results and Discussion}

The demographic that were considered for this study were Gender, Age, Level of Education and ability to use mobile phone device to access library services. It was established that a $68.75 \%$ of the respondents were male while $31.25 \%$ were females. Both groups had at least a $25 \%$ representation in the study. In relation to age it was established that $33.98 \%$ of the respondents were between the ages $31-40$ years and that they were Male. $34.75 \%$ of the respondents were between the ages $20-30$ years and that they were female. Only $1.02 \%$ was above 45 years old and male, while $0.89 \%$ was females in the same age bracket. Thus, the majority of the respondents were 45 years and below. $51.67 \%$ of the respondents were male respondents with bachelor's degree while $45.12 \%$ were females with a bachelor's degree, $15.10 \%$ of the respondents were males with postgraduate degree while $12.21 \%$ were females in the same level of education.
Of the remaining $2.02 \%$ of the male respondents were in the process of enrolling for a doctorate degree and $0.52 \%$ of the females were in the same bracket. Majority of the respondents had enrolled for bachelor's degree while a few completed college diploma and stopped there.

In relation to use of mobile phone, $37.24 \%$ of the respondents were males who owned and were capable of using phones to access library services and $25.53 \%$ were females in the same group whereas the remaining $8.49 \%$ of the respondents were males who neither owned a phone nor used it to access and utilize library services. $4.89 \%$ of respondents who were didn't own a phone hence could not use it to access library services. It is vivid that the highest percentage of respondents were males who owned and used mobile phones to access library services but least percentage is recorded for females not owning phone nor using it. In order to answer the first objective, respondents were asked to state ways of accessing library services. All respondents indicated that they hadn't fully embraced mobile phone technology in access to library services. However, there was evidence of use of mobile phone to access library services.

The study further noted that training of library users on how to use phones to access library services is important but little has been achieved in that exercise. $69.12 \%$ males' and $50.02 \%$ females' respondents indicated that they hadn't been trained by library staff on use of mobile phones to access library services. Nevertheless, there was significant attempts to use phone to access library services; $33.56 \%$ males and 40.24 females respondents used phones to access MKU Online public Access Catalogue, 23.54\% males and 25.12\% females respondents access their library account, mange it and renew borrowed resources and $45.12 \%$ males and $40.12 \%$ females respondents access MKU E-repository and e-journals through their handsets. Majority of respondents have used mobile phones to access, manage and utilize their library accounts and library services and resources.

In order to meet the second objective, the factors were categorized into six parts, namely: Borrowing through circulation counter; Access to e-resources in e-learning section; Downloading and saving in e-books readers and phones; Online Public Access Catalogue; Online renewal of borrowed materials and E-repository. In each part, the respondents were asked to give if mobile phone were capable of accessing the following library services and how often do they use them as in the table below;

Table 1. Capability of mobile phones to access library services

\begin{tabular}{|c|c|c|c|c|c|}
\hline Library services & Never & Rarely & Often & Very often & Always \\
\hline Borrowing through circulation counter & $64(16.00 \%)$ & $53(13.25 \%)$ & $61(15.25 \%)$ & $71(17.75 \%)$ & $151(37.75 \%)$ \\
\hline Access to e-resources in e-learning section & $67(16.75 \%)$ & $60(15.00 \%)$ & $40(10.00 \%)$ & $88(22.00 \%)$ & $145(36.25 \%)$ \\
\hline $\begin{array}{c}\text { Downloading and saving in e-books } \\
\text { readers and phones }\end{array}$ & $65(16.25 \%)$ & $60(15.00 \%)$ & $74(18.50 \%)$ & $41(10.25 \%)$ & $160(40.00 \%)$ \\
\hline Online Public Access Catalogue & $63(15.75 \%)$ & $50(12.50 \%)$ & $42(10.50 \%)$ & $188(47.00 \%)$ & $57(14.25 \%)$ \\
\hline Online renewal of borrowed materials & $65(16.25 \%)$ & $80(20.00 \%)$ & $70(17.50 \%)$ & $55(13.75 \%)$ & $130(32.50 \%)$ \\
\hline E-repository & $65(16.25 \%)$ & $67(16.75 \%)$ & $18(4.50 \%)$ & $90(22.50 \%)$ & $160(40.00 \%)$ \\
\hline
\end{tabular}


Table 2. Library Services accessible via Mobile Phone Devices

\begin{tabular}{|c|c|c|c|c|}
\hline & Type of Service & Yes & No & Not Sure \\
\hline a. & Full text journals articles & $210(52.50 \%)$ & $50(12.50 \%)$ & $140(35.00 \%)$ \\
\hline b. & $\begin{array}{c}\text { Online Public Access Catalogue } \\
\text { (OPAC) }\end{array}$ & $290(72.50 \%)$ & $80(20.00 \%)$ & $130(32.50 \%)$ \\
\hline e.. & Electronic Books & $310(77.50 \%)$ & $10(0.02 \%)$ & $80(20.00 \%)$ \\
\hline f.. & Library Website & $299(74.75 \%)$ & $96(24.00 \%)$ & $5(1.25 \%)$ \\
\hline h.. & Current Awareness services & $250(62.50 \%)$ & $98(24.50 \%)$ & $52(13.00 \%)$ \\
\hline
\end{tabular}

According to Table 1,37.75\% agreed that mobile phones were capable enabling borrowing of books through the circulation counter and confirmed to have used it always, while $13.25 \%$ indicated to have rarely used the service. Access to e-resources received $36.25 \%$ where respondents felt that phone enabled them to utilize these resources while $10.00 \%$ reported use mobile phone very often to access similar services. $40.00 \%$ of the respondents confirmed to have always used phones to download and save e-books where only $10.25 \%$ indicated to have used the service very often. $47.00 \%$ respondents used phones to access MKU Online Public access Catalogue to peruse through the library holdings whereas, $12.50 \%$ often use it. Student respondents confirmed to have used phones to renew materials they borrowed from the library represented by $32.50 \%$ who always used it against $13.75 \%$ who used the phones very often for same purpose. $40.00 \%$ respondents agreed to have used mobile phones to access MKU E-repository against $4.50 \%$ respondents who access similar service but often. It was evident majority of respondents agree that mobile phone technology access and utilization of library services.

In order to find out whether the library management system in MKU has laid down necessary strategies to support mobile phone technology access to and utilization of library services and identify services accessible through the mobile phone technology.

From table 2, 77.5\%, $74.75 \%$ and $72.50 \%$ respondents agreed to have used mobile phone device to gain access to e-books, library website and MKU OPAC respectively. Only $52.50 \%$ respondents indicated to have accessed e-journals through phone. Overall, it is encouraging to find out that MKU academic library users and staffs have embraced mobile phone access to its holdings. $24.50 \%$ respondents were the highest score recorded not used phones to access a library services against the lows of $0.02 \%$ respondents. Additionally, when respondents were required to answer if they not sure of use of mobile phone technology to access library services, $35.00 \%$ was the highest recorded score against $1.25 \%$ as the lowest. Therefore, in all the services that were put under investigation, respondents showed a keener interest in the access and utilization of the same via mobile phone. Respondents who never used or not sure of the latest technology, even when combined their percentage was below average. As a result, MKU library is headed to the right direction as far as adoption and use of technology and service delivery.
When asked about the challenges that are currently facing the full implementation of mobile phone technology in MKU libraries, $56 \%$ respondents cited internet failure, $30 \%$ cited lack of training and $14 \%$ indicated lack willingness from other library users to use mobile technologies. While interviewing the library staff, they reported that management is in the process of improving internet services in order to serve customers well. Although training have been conducted in the past, they weren't sufficient to improve library users' skills in relation to access and utilization of library services via mobile phone technology. Reluctance and resistance represented by $14 \%$ respondents is minimal and can be overcome over time. When all systems go for mobile technology, this group will eventually follow suit.

Researcher sought to find out how the challenges reported can be solved, $40 \%$ respondents indicated that quarterly training for both staff and users is required, $20 \%$ respondents proposed internet bandwidth to be increased in all libraries and the remaining proposed regular sensitization for all students to ensure understanding the need for this technology in the library setting.

\section{Conclusions and Recommendations}

The findings of this study show that there is significant use of mobile phone technology in access and utilization of library services. In Mount Kenya University, the university has invested in library automation and installation of library management system to create a platform for mobile phone technology to access and utilize library services. Although some libraries are still young in technological adoption and use, MKU library has shown the way. The finding indicated that both men and women own mobile phone and use them to access library services. Since almost a half of the respondents use mobile phones, library staff members to undertake regular trainings, seminars and workshops to enlighten users on possibility of accessing better services via phones. This will also go a long way with providing library services even to remote areas and users will be granted opportunities to renew materials borrowed. In addition, students enrolled in various modes of study will be catered for since one need not to appear physically in the library to use it.

Regarding the services accessible via mobile phone, both patrons and library staff have a responsibility in equal measures. Librarians and information professionals should 
go out of their way to market library holdings through Current Awareness programmes, orientation of students and hold thorough training for their users. Patrons should also try to embrace technology as presented in the library platform of access to their resources. They should also be willing to learn from other people including staff members.

Based on objective two; capability of mobile phone technology in accessed and utilized of library services in Mount Kenya University library services, respondents indicated that there flexible access to most of library services, quick perusal of library holdings and virtual access and utilization. With this flexibility, users can be served from wherever they may be.

As a result of the findings obtained from the study the following are recommended. The Government through the Ministry of Education should initiate and support training programmes in all academic institutions on use of mobile phone technology in access and utilization of library services. Seminars and workshops should done involving all the stakeholders in various academic libraries. This will go a long way with providing library services to students who enrolled for virtue academic programmes. Since universities have started offering distance learning programmes, it pertinent if this proposal is brought into fruition. This should go beyond general policy provisions by including pro-active policy interventions, designing an elaborate financial support to academic libraries, and entrenching competition and technology transfer for faster and convenient access to libraries.

With the advent of mobile phone technology, libraries will be capable of providing services without boundaries. Training of library and information professionals must include the technological aspect in order maintain relevance in service delivery. Universities, colleges and other learning institutions need to create a platform which will support the use of this technology in their libraries.

\section{REFERENCES}

[1] Ahmed, A., Raza, A., \& Sadik, S. (2014). User's Perspective of Smartphone Platforms Usability: An Empirical Study (pp. 379-384). IEEE. http://doi.org/10.1109/ISMS.2014.70

[2] Ali, A., Alrasheedi, M., Ouda, A., \& Capretz, L. F. (2014). A Study of The Interface Usability Issues of Mobile Learning Applications for Smart Phones from the User's Perspective. International Journal on Integrating Technology in Education, 3(4), 1-16. http://doi.org/10.5121/ijite.2014.3401

[3] Ahmed, A., Raza, A., \& Sadik, S. (2014). User's Perspective of Smartphone Platforms Usability: An Empirical Study (pp. 379-384). IEEE. http://doi.org/10.1109/ISMS.2014.70

[4] Ali, A., Alrasheedi, M., Ouda, A., \& Capretz, L. F. (2014). A Study of The Interface Usability Issues of Mobile Learning Applications for Smart Phones from the User's Perspective. International Journal on Integrating Technology in Education, 3(4), 1-16. http://doi.org/10.5121/ijite.2014.3401
[5] Cummings, J., Merrill, A., \& Borrelli, S. (2010). The use of handheld mobile devices: their impact and implications for library services. Library Hi Tech, 28(1), 22-40. http://doi.org/10.1108/07378831011026670

[6] Dinkelman, A., \& Stacy-Bates, K. (2007). Accessing e-books through academic library web sites. College \& Research Libraries, 68(1), 45-58.

[7] Gay, L. R. (2005). Educational research: Competencies for analysis and application (7th ed.). Upper Saddle River, NJ: Pearson Education.

[8] Gitau, S., Marsden, G., \& Donner, J. (2010). After access: challenges facing mobile-only internet users in the developing world. In Proceedings of the SIGCHI Conference on Human Factors in Computing Systems (pp. 2603-2606). ACM. Retrieved from http://dl.acm.org/citation.cfm?id=175 3720

[9] Ishii, K. (2004). Internet use via mobile phone in Japan. Telecommunications Policy, 28(1), 43-58.http://doi.org/10.1 016/j.telpol.2003.07.001

[10] Lenhart, A. (2009). Teens and mobile phones over the past five years: Pew Internet looks back. Pew Internet \& American Life Project Washington, DC. Retrieved from http://www.pewinternet.org/files/old-media/Files/Reports/20 09/PIP\%20Teens\%20and\%20Mobile\%20Phones\%20Data\% 20Memo.pdf

[11] Lenhart, A. (2012). Teens, smartphones \& texting. Pew Internet \& American Life Project. Retrieved from http://www.unav.edu/matrimonioyfamilia/observatorio/uploa ds/29710_Pew-Internet-Lenhart_Teens-smartphones-2012.p $\mathrm{df}$

[12] Lester, R. T., Ritvo, P., Mills, E. J., Kariri, A., Karanja, S., Chung, M. H.,... others. (2010). Effects of a mobile phone short message service on antiretroviral treatment adherence in Kenya (WelTel Kenya1): a randomised trial. The Lancet, 376(9755), 1838-1845.

[13] Lippincott, J. K. (2010). A mobile future for academic libraries. Reference Services Review, 38(2), 205-213. http://doi.org/10.1108/00907321011044981

[14] MacWhinnie, L. A. (2003). The information commons: the academic library of the future. Portal: Libraries and the Academy, 3(2), 241-257.

[15] Maranto, T., Phang, S., \& Hartman, K. (2010). Mobile Phone Access in Sub-Saharan Africa: Research and A Library Proposal. In Seminar in International and Comparative Librarianship. Citeseer. Retrieved from http://citeseerx.ist.ps u.edu/viewdoc/download?doi=10.1.1.476.873\&rep=rep1\&ty $\mathrm{pe}=\mathrm{pdf}$

[16] Mutula, S. M. (2002). The cellular phone economy in the SADC region: implications for libraries. Online Information Review, 26(2), 79-92. http://doi.org/10.1108/146845202104 24548

[17] Onyango, R. A., Ongus, R. W., Awuor, F. M., \& Nyamboga, C. (2014). Impact of Adoption and Use of Mobile Phone Technology on the Performance of Micro and Small Enterprises in Kisii Municipality Kenya. World Journal of Computer Application and Technology, 2(2), 34-42.

[18] Pomerantz, J., \& Marchionini, G. (2007). The digital library as place. Journal of Documentation, 63(4), 505-533. 
[19] Rieger, R., \& Gay, G. (1997). Using mobile computing to enhance field study. In Proceedings of the 2nd international conference on Computer support for collaborative learning (pp. 218-226). International Society of the Learning Sciences. Retrieved from http://dl.acm.org/citation.cfm?id=1599800

[20] Simmonds, P. L., \& Andaleeb, S. S. (2001). Usage of academic libraries: Role of service. Library Trends, 49(4), 626-34.

[21] Varshney, U., \& Jain, R. (2001). Issues in emerging 4G wireless networks. Computer, 34(6), 94-96.
[22] Wyche, S. P., Densmore, M., \& Geyer, B. S. (2015). Real mobiles: Kenyan and Zambian smallholder farmers' current attitudes towards mobile phones (pp. 1-10). ACM Press. http://doi.org/10.1145/2737856.2738013

[23] Zhang, L., Tiwana, B., Qian, Z., Wang, Z., Dick, R. P., Mao, Z. M., \& Yang, L. (2010). Accurate online power estimation and automatic battery behavior based power model generation for smartphones. In Proceedings of the eighth IEEE/ACM/IFIP international conference on Hardware/software codesign and system synthesis (pp. 105114). ACM. Retrieved from http://dl.acm.org/citation.cfm?id $=1878982$ 